\title{
Does Urban Rail Increase Land Value in Emerging Cities? Value Uplift from Bangalore Metro
}

\author{
Rohit Sharma*, Peter Newman** \\ Curtin University Sustainability Policy Institute, Curtin University, Australia \\ Building 209, Bentley, Perth 6845 WA, Australia. \\ *E-mail: rohitsharma16@gmail.com \\ **E-mail: p.newman@curtin.edu.au
}

\section{Highlights}

1. There is a significant willingness to pay for urban rail in the emerging city of Bangalore.

2. Land value increases beyond the traditional $500 \mathrm{~m}$ catchment area of $25 \%$.

3. Panel data hedonic price modeling shows over $4 \%$ increase in the whole city's land value.

4. Urban rail projects have potential for a major agglomeration economic event in emerging cities.

\section{Abstract}

This paper seeks to understand how urban rail can influence land value uplift, especially in emerging cities which are largely unstudied. It examines the Bangalore Metro and shows that the uplift from the metro rail was substantial in the 'catchment area' and 'across the city'. The analysis was based on the panel data hedonic price model for around 160,000 apartments over the period 2012-16 and a crosssectional data hedonic price model for 314,000 apartments in 2016. The panel data resulted in a stronger model and show significant land value increases, even beyond the traditional $500 \mathrm{~m}$ catchment (Figure 1). A 'before' and 'after' from the commencement of the metro rail operations shows a price uplift of $4.5 \%$ across the whole city and indicates a major agglomeration economic event resulting in substantial willingness to pay of USD 306 million from the metro rail accessibility. Emerging cities can expect metro rail to substantially improve their economies and other co-benefits as long as finance can be obtained by capturing this value. 


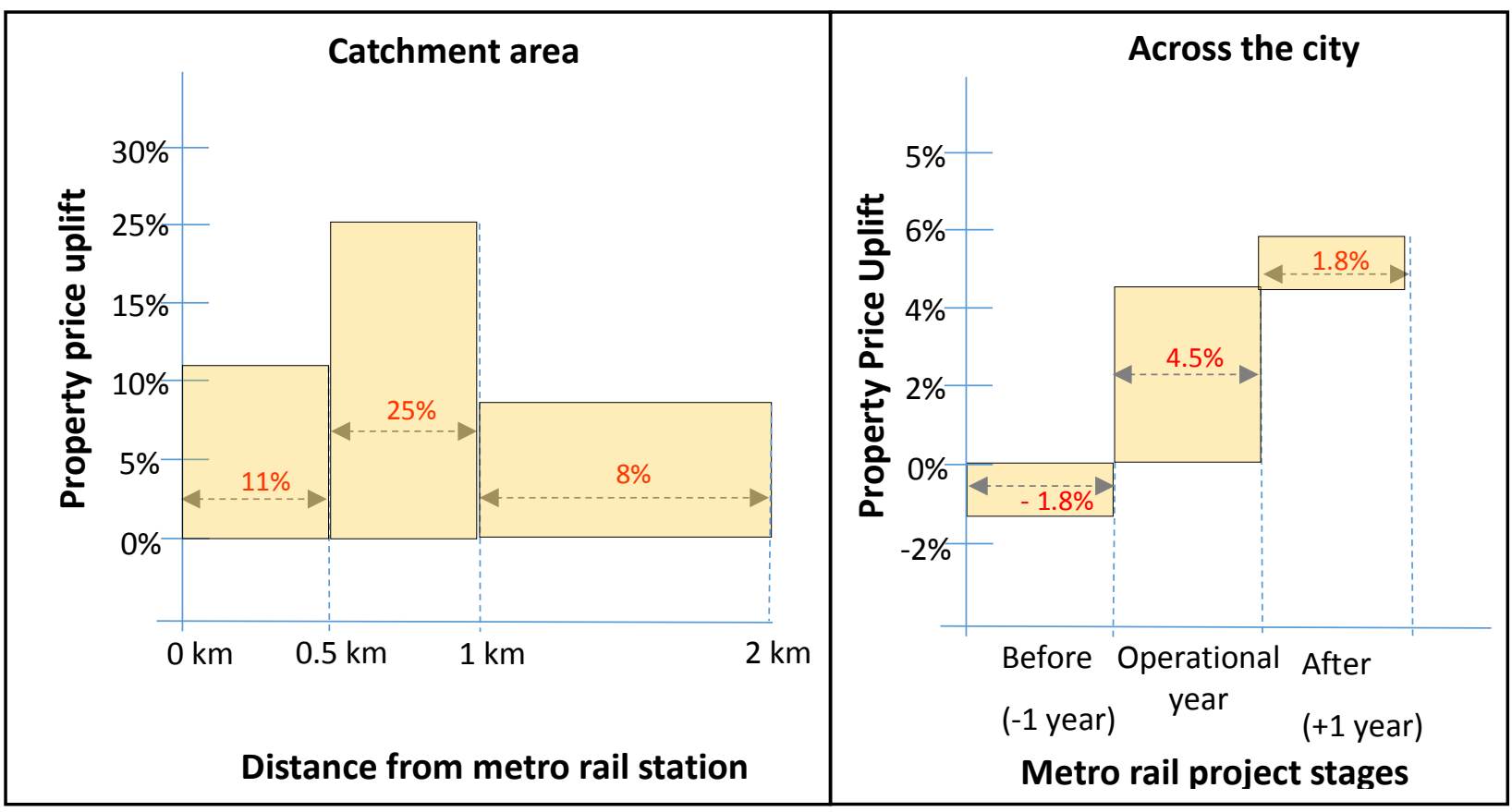

Figure 1: Impact of metro rail on property price

Keywords: Urban rail; land value capture; emerging cities; hedonic price model; agglomeration economics.

\section{Introduction}

In the latter half of the $20^{\text {th }}$ century, governments favoured urban road systems and failed to allocate substantial public funds for urban rail projects. This approach contributed to removal of urban rail across most of the cities around the globe in the 1950's and 1960's. Those that remained like London and New York's subway were significantly underfunded (Black 2007; Green, 2016; Sharma \& Newman, 2017).

Urban rail is back on the urban development agenda. It is thriving in densely populated cities of Asia, Europe and the Middle East and in the American and Australian cities which are heavily reliant on cars. Over the last two decades, China and India introduced over 25 high capacity urban rail systems (metro rail) with another 25 currently under construction ${ }^{1}$. This surge is driven largely by rapidly growing demand for rail in cities due to increasing travel time differentials between urban rail and urban traffic as well as a growing need for dense urban centers that are facilitated by urban rail. However, financing remains a constant struggle with the conventional model of government grants and fare-box revenue proving to be inadequate to meet the increasing rail demand. An alternative is the need to realize the

\footnotetext{
${ }^{1}$ In addition to urban rail, China is constructing $18,000 \mathrm{~km}$ network of high-speed rail to support its growing economy (Chen, 2012).
} 
economic benefits of urban rail and use it for its financing (Debrezion, Pels \& Rietveld, 2007; Newman, Kenworthy \& Glazebrook, 2013; Newman \& Kenworthy, 2015; Sharma, 2018).

Land value capture (LVC) mechanisms have shown significant potential as a sustainable source of finance for urban rail projects. This financing alternative emerges from the potential of urban rail to increase the land value in transit catchment. Most of the LVC studies have been done on cities in developed nations. This paper seeks to enable a better understanding of LVC in emerging cities as the need for alternative funding is even more significant in emerging cities where there is high deficit in social infrastructure as well as lean budgets.

It is speculated that urban rail (metro rail) has increased real estate value in Indian cities (Jillella \& Newman, 2016; Ministry of Urban Development [MoUD], 2012; Shankar, 2015) but there are unanswered questions on how to quantify the value uplift and willingness to pay (WTP) for accessibility. This paper attempts to answer these questions in stages. It begins by examining the relevance of location theory, land rent and demand, and WTP for transit infrastructure in any city including emerging cities to see how metro rail influences land value. The subsequent section discusses prominent studies on residential land value uplift due to metro rail in developing and developed countries based on the hedonic price model (HPM) method. Following this, a methodology is proposed to evaluate the impact of metro rail (as a property attribute) on the residential property market using HPM to estimate user's WTP. The methodology is applied to the Indian case of Bangalore ${ }^{2}$. The case study uses cross sectional and panel data to prepare HPM's for calculating WTP for different property attributes, particularly metro rail accessibility. The estimated HPM's are used to capture the increase along the metro rail catchment land market and at city-level. The latter is rarely done in LVC studies.

In the next sections, theory is used to show a) why particular HPM variables were chosen to evaluate land value in Bangalore and b) how the land value uplift can be explained.

\section{Literature Review}

\subsection{Urban Rail and Real Estate}

Table 1 shows that urban rail uplifts residential real estate (land and property) value in cities around the globe. This value appreciation could be captured to finance urban rail (see Anantsuksomsri \& Tontisirin, 2015; Armstrong \& Rodriguez, 2006; Cervero, 2003; Du \& Mulley, 2007; Garrett, 2004; Iacono et al., 2009 Mclntosh, Trubka \& Newman, 2014; Medda \& Modelewska, 2009; Sharma \& Newman, 2018; Yankaya, 2004).

\footnotetext{
2 The name of the city is officially Bengaluru since 2014, but the old name is used for convenience with references.
} 
Value capture requires that the extent of impact in a city be quantified, followed by analyzing if urban rail generates sufficient value (demand - WTP) to be captured. Econometric models have been extensively used to assess the impact of urban rail on real estate. The most popular among these models is the hedonic price model (HPM).

\subsection{Hedonic Price Model (HPM)}

The HPM is a regression model with its basis in economic thinking of the early $20^{\text {th }}$ century. It involves the application of least squares regression analysis which requires a linear relationship between the dependent variable (eg. property value) and independent (explanatory) variables (eg. characteristics of property). It estimates separately the contribution of each independent variable price to the total estimated (hedonic) price. The HPM functional forms include linear, linear-log, log-linear and log-log. Equation 1 represents the equation for the observed dependent variable (D) (McIntosh, Trubka \& Newman, 2014; Rosen, 1974; Sopranzetti, 2015).

Equation 1 Parametric Land Price Equation

$$
D_{i}=f\left(X_{j} ; \beta_{j}\right)+\varepsilon_{i}
$$

Where
$D_{i} \quad$ is the estimated land price of the $i^{\text {th }}$ observation,
$\mathrm{X}_{\mathrm{j}} \quad$ is a vector of quantitative and qualitative property attributes,
$\beta_{\mathrm{j}} \quad$ is the unknown hedonic price of the property for attribute $\mathrm{j}$, and
$\varepsilon_{\mathrm{i}} \quad$ is the stochastic error term.

\subsection{Location Theory}

Von Thunen's (1826) classic location theory analyzed the spatial division of different production activities to minimize transportation expenses between production area and marketplace (Fischer \& Nijkamp, 2014). His concepts were applied to urban activities by Hurd (1903), Haig (1926) and Ratcliff (1949) to suggest that urban activities reflect rent competition for locations that minimize movement. On the other hand, Robert Park (1929) theorized that improvement in transportation and population growth augments benefits of the city center. Alonso (1964) built his location theory based on earlier pioneering studies (Isard, 1956 and Wingo, 1961) to suggest that minimization of transportation cost (spatial friction) between residence and work increases land rent in urban settings, as high accessibility to central areas activates competition for locations closer to the central business district (CBD) (Capello, 2011). 
The above location theories when applied to an urban context, essentially explain the economic rationale of choosing to situate a firm or household at a specific location in an urban space to minimize transportation costs in the context of agglomeration economies (Capello, 2011). The primary consideration in selecting the location for an urban household is to ensure efficient access to the benefits of agglomeration viz. urban resources, services and workplaces. Thus, location theories highlight the significance of activity centers and travel time in a city.

Saving on travel time is economically significant in a city as it contributes to decreases in transportation and opportunity cost. Over the last decade travel time by car has exceeded that by urban rail in cities across the globe (Newman \& Kenworthy, 2015). The importance of saving on travel time is driving the demand for urban rail that is further catering to the urban knowledge economy and the culture of people-centered urban form to support this process (Matan \& Newman, 2016; Glaeser, 2011).

Based on the above discussion, this study examined HPM variables on activity centers, urban infrastructure, locational attributes, density and mixed land use as factors affecting the residential land market in Bangalore.

\subsection{Urban Land Rent}

An important feature common to urban location choice theories is the cost of land, or land rent (Capello, 2011). Urban land rent represents the manifestation-in price terms-of the economic value of a scarce resource, e.g. urbanized land endowed with general accessibility characteristics (to the center and to specific facilities like railway stations, airports, parks and green areas) or agglomeration benefits discussed above.

Camagni (2016) suggests that rent emerges from two preconditions, first being a limited supply that leads to a 'scarcity absolute rent' (Scott, 1976; Sraffa, 1960) and the second, a 'demand for city' i.e. a household's willingness to pay more than the supply cost for a desirable good or production factor such as access to transit. This demand is generated by the need to benefit from an urban environment which is a product of agglomeration economies. Demand may increase due to time/space specificities when a city becomes crucial for economic activities, for instance the knowledge economy emerges or a city provides an innovative environment or introduction of a public urban infrastructure like metro rail (Camagni, 1992, as cited in Camagni, 2016).

\subsection{Urban Land Demand}

As a scarce resource, urban land displays certain peculiar characteristics to qualify as a marketable commodity (Johnston, 1977, as citied in Kivell \& Shaw, 1988). It plays a role in optimization processes in the locational choice of actors, in allocation decisions of land-owners, and in minimizing of mobility and interaction costs. These processes and characteristics contribute to the demand of urban land. 
Alonso (1964) suggested that the demand of urban land is a utility function of the characteristics of land, geographical location and income constraint. He suggested that an individual household buyer trades off between accessibility, land characteristics and money to reach a decision. The trade-off forms a three-dimensional relationship to represent householder's equilibrium demand. He expressed this in the form of bid-rent curves: the householder's indifference surfaces yield a set of alternative combinations of price and quantities of land at a location for required income and transport costs (Kirwan, 1966).

Muth (1969) accorded Alonso (1964) on the positive relationship of land value with its proximity to a CBD. Muth (1969) expanded Alonso's model and showed that population density and proximity to CBD are relative to household income and age of dwellings. Alonso (1964) added that the only way to channel high income demand for land back to central areas ${ }^{3}$ is by up-zoning it (as cited in Kirwan, 1966).

Based on these urban rent and demand theories, a city-level assessment of urban rail impact on residential land markets was conducted on Bangalore in order to assess if urban rail results in agglomeration benefits at city level in addition to the generally accepted impacts on catchment areas.

\subsection{HPM Case Studies - Influence of urban rail on residential real estate}

Table 1 presents a compilation of case studies on the impact of urban rail on residential value using HPM. The compilation includes eleven cases from developed countries and six from developing countries along with their findings, methodology, functional form, and dependent (land/ property price) and differing independent variables. The selected case studies (1992 to 2015) provide a temporal outlook on the subject over the past two decades. There are many more studies on developed cities but these six seems to cover those on emerging cities.

The difference in availability of property records in the various case studies reflects a contrasting situation between developing and developed countries. While the cities of developed countries have organized database and property transaction records, the same appears to be lacking in the studies from developing countries. For instance, the cases of Seoul, Izmir, Beijing and Taipei reply on a small sample size of about 350 observations each. The study from Bangkok manages 622 observations being the most recent. While all the cases, the value of $R^{2}$ appeared to be independent of the number of observations used in each study, the nature of the city, the model used or the resultant impact ${ }^{4}$.

\footnotetext{
${ }^{3}$ Park (1952) noted that in 1960's the low-dense American suburban land value was increasing and the city centre value was decreasing.

${ }^{4}$ Nagelkerke (1991, p. 161) defined $R^{2}$ as "the proportion of variance 'explained' by the regression model useful as a measure of success of predicting the dependent variable from the independent variables". As per Gujarati \& Porter (2004), $\mathrm{R}^{2}$ in cross sectional data is generally low due to the inherent diversity of cross sectional data. An HPM is considered acceptable or satisfactory if the
} 
In the studies from developing countries, the database has been expanded by using a wide range of structural, neighborhood, accessibility and time based variables to compensate for lesser number of observations. The studies from developed countries analyzed datasets ranging from 1,000 to 124,000 observations and a fair range of variables. Cases from the United States of America (USA) include details on building utility and structural variables. All other cases, especially from developing countries, collect a substantial number of neighborhood variables like presence of parks, schools, health centers, convenience shops, sports facilities and water bodies.

The cases from USA suggest a substantial proximity premium, ranging from $10 \%$ to $34 \%$ for the proximity variable from $60 \mathrm{~m}$ to $800 \mathrm{~m}$ around a railway station. The Helsinki, Warsaw and Tyne \& Wear studies show $11 \%, 7 \%$ and $17 \%$ proximity premium at $500 \mathrm{~m}, 1 \mathrm{~km}$ and $200 \mathrm{~m}$ proximity variable respectively. The Lisbon Metro rail case registers a $9 \%$ impact on average from the accessibility attribute. Contrary to expectations, the cases from developing countries suggest low impact on accessibility, except in the case of Izmir Subway and Bangkok Mass Transit System. The Izmir case study places a proximity premium at up to $16 \%$ for properties within $1 \mathrm{~km}$ of the transit station and the Bangkok study places it at USD 9,210 per $1 \mathrm{~km}$ closer to the transit station. Factors such as typology and quality of housing registered considerable impact in the Asian cases of Beijing and Seoul.

These case studies indicate that LVC has significant potential but it needs further development in emerging cities through better data and more parameters to explore the impact of urban rail accessibility on WTP and hence LVC. The paper thus moves to a more advanced study of Bangalore using better data and more parameters than have been used in other emerging cities. 
Table 1: Authors' compilation of HPM studies on impact of urban rail in real estate value

\begin{tabular}{|c|c|c|c|c|c|c|c|c|c|c|}
\hline \multirow[b]{2}{*}{$\begin{array}{l}\text { SI. } \\
\text { No. }\end{array}$} & \multirow{2}{*}{ Author } & \multirow{2}{*}{$\begin{array}{l}\text { Location } \\
\text { - Transit } \\
\text { System }\end{array}$} & \multirow{2}{*}{$\begin{array}{c}\text { HPM } \\
\text { Form: } \\
\text { Model } \\
\mathbf{R}^{2}\end{array}$} & \multirow{2}{*}{\begin{tabular}{|c|} 
Depend \\
ent \\
Variabl \\
e
\end{tabular}} & \multicolumn{4}{|c|}{ Independent Variables } & \multirow[b]{2}{*}{$\begin{array}{c}\text { Data \& } \\
\text { Methodology }\end{array}$} & \multirow[b]{2}{*}{ Finding(s) from HPM } \\
\hline & & & & & $\begin{array}{c}\text { Land/Structur } \\
\text { al }\end{array}$ & $\begin{array}{c}\text { Neighbour } \\
\text { hood }\end{array}$ & $\begin{array}{l}\text { Accessibility } \\
\text { (Distance to) }\end{array}$ & Time Based & & \\
\hline 2 & \begin{tabular}{|l} 
Lin \& \\
Hwang \\
$(2004)$
\end{tabular} & $\begin{array}{l}\text { Taipei, } \\
\text { Taiwan - } \\
\text { Taipei } \\
\text { Metro }\end{array}$ & $\begin{array}{l}\text { Linear: } \\
0.766\end{array}$ & $\begin{array}{l}\text { Property } \\
\text { price }\end{array}$ & $\begin{array}{l}\text { - Floor space } \\
\text { - Building age }\end{array}$ & - & $\begin{array}{l}\text { - CBD } \\
\text { - Public } \\
\text { facility } \\
\text { - Transit } \\
\text { station }\end{array}$ & $\begin{array}{l}\text { - Economic } \\
\text { growth rate } \\
\text { - Consumer } \\
\text { price index } \\
\text { - Time of the } \\
\text { year }\end{array}$ & $\begin{array}{l}\text { Panel data of } 317 \\
\text { residential property } \\
\text { located within } 400 \mathrm{~m} \\
\text { from metro rail line, } \\
\text { from } 1993 \text { to } 1995 . \\
\\
\text { Time dummy variable } \\
\text { for before and after } \\
\text { operation of metro } \\
\text { rail. }\end{array}$ & $\begin{array}{l}\text { Floor space price increased } \\
\text { at about USD } 480 \text { per } \\
\text { sq.m., after subway } \\
\text { opening along the corridor. }\end{array}$ \\
\hline
\end{tabular}




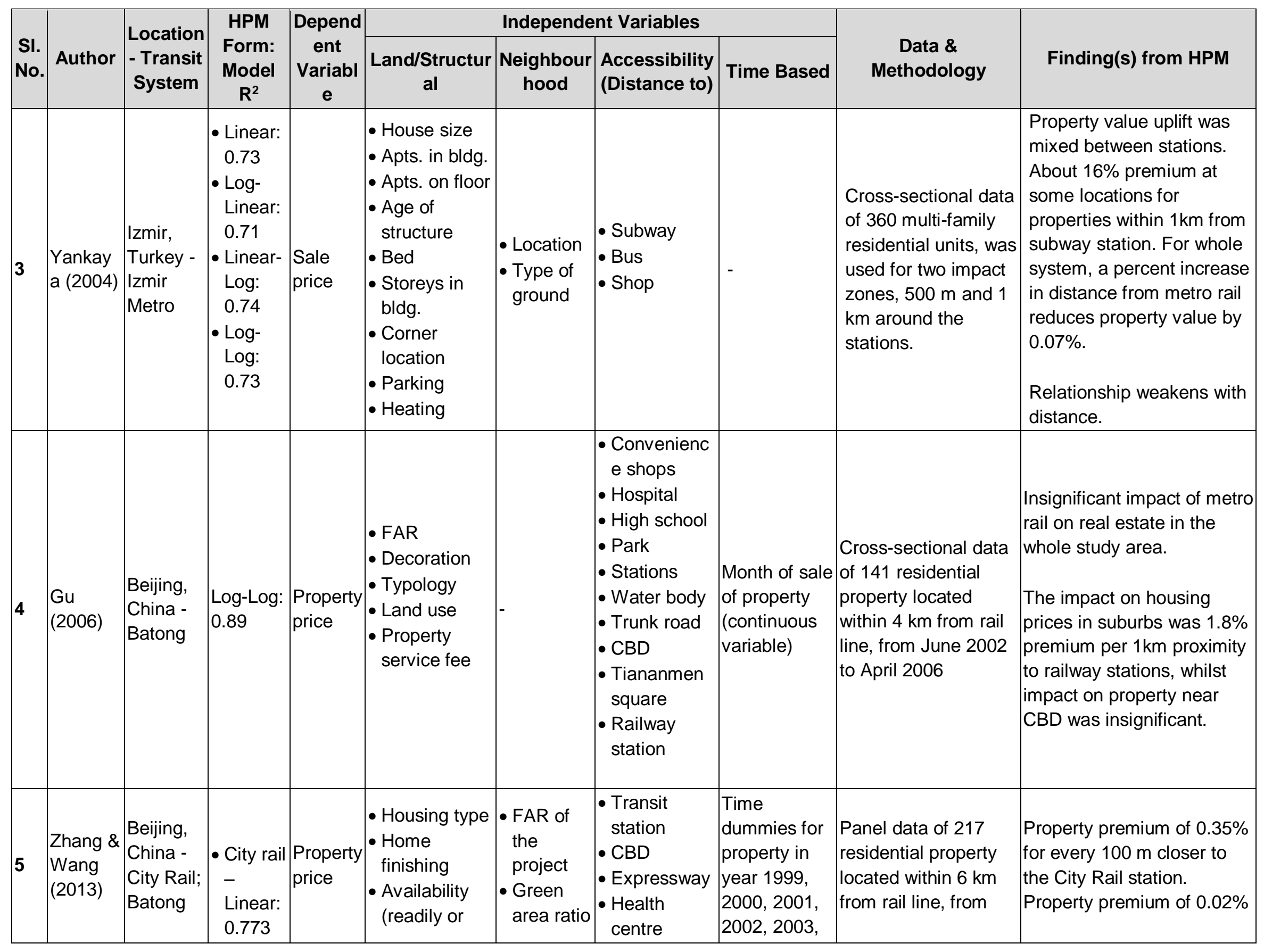




\begin{tabular}{|c|c|c|c|c|c|c|c|c|c|c|}
\hline \multirow[b]{2}{*}{$\begin{array}{l}\text { SI. } \\
\text { No. }\end{array}$} & \multirow[b]{2}{*}{ Author } & \multirow{2}{*}{$\begin{array}{l}\text { Location } \\
\text { - Transit } \\
\text { System }\end{array}$} & \multirow{2}{*}{$\begin{array}{l}\text { HPM } \\
\text { Form: } \\
\text { Model } \\
\mathbf{R}^{2}\end{array}$} & \multirow{2}{*}{\begin{tabular}{|c|} 
Depend \\
ent \\
Variabl \\
e
\end{tabular}} & \multicolumn{4}{|c|}{ Independent Variables } & \multirow[b]{2}{*}{$\begin{array}{c}\text { Data \& } \\
\text { Methodology }\end{array}$} & \multirow[b]{2}{*}{ Finding(s) from HPM } \\
\hline & & & & & $\begin{array}{c}\text { Land/Structur } \\
\text { al }\end{array}$ & $\begin{array}{c}\text { Neighbour } \\
\text { hood }\end{array}$ & $\begin{array}{l}\text { Accessibility } \\
\text { (Distance to) }\end{array}$ & Time Based & & \\
\hline 6 & $\begin{array}{l}\text { Anantsu } \\
\text { ksomsri } \\
\& \\
\text { Tontisiri } \\
\text { n (2015) }\end{array}$ & $\begin{array}{l}\text { Bangkok, } \\
\text { Thailand } \\
\text { - Mass } \\
\text { Transit } \\
\text { System }\end{array}$ & $\begin{array}{l}\text { Linear: } \\
0.56\end{array}$ & $\begin{array}{l}\text { Land } \\
\text { price }\end{array}$ & - & - Populatio & $\begin{array}{l}\text { - } \text { Metro } \\
\text { station } \\
\text { - Arterial road } \\
\text { - CBD } \\
\text { - Airport } \\
\text { - Hospital } \\
\text { - Park } \\
\text { - School } \\
\text { - University }\end{array}$ & 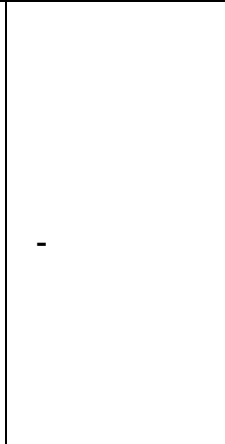 & $\begin{array}{l}\text { Cross-sectional data } \\
\text { of } 622 \text { residential } \\
\text { property located } \\
\text { within Bangkok } \\
\text { Metropolitan Region } \\
\text { for year } 2010 .\end{array}$ & $\begin{array}{l}\text { USD } 9210 \text { premium on land } \\
\text { value per } 1 \mathrm{~km} \text { proximity to } \\
\text { transit station. }\end{array}$ \\
\hline 7 & $\begin{array}{l}\text { Laakso } \\
(1992)\end{array}$ & $\begin{array}{l}\text { Helsinki, } \\
\text { Finland - } \\
\text { Helsinki } \\
\text { Metro }\end{array}$ & $\begin{array}{l}\text { Log- } \\
\text { Linear: } \\
0.94\end{array}$ & $\begin{array}{l}\text { Sale } \\
\text { price }\end{array}$ & $\begin{array}{l}\text { - Ln (Age) } \\
\text { - Ln (Area) } \\
\text { - Terrace } \\
\text { House } \\
\text { - Pool } \\
\text { - Indoor sports } \\
\text { - Health centre } \\
\text { - Library } \\
\text { - Daycare }\end{array}$ & $\begin{array}{l}\text { - Ln } \\
\text { \%Park } \\
\text { - Ln } \\
\text { Income } \\
\text { quartile }\end{array}$ & $\begin{array}{l}\text { - Metro } \\
\text { station } \\
\text { dummies } \\
\text { - Feeder bus } \\
\text { dummies } \\
\text { - Commuter } \\
\text { rail dummy } \\
\text { - Shopping } \\
\text { centre } \\
\text { dummy } \\
\text { - Coast } \\
\text { - Ln CBD }\end{array}$ & $\begin{array}{l}\text { - Transaction } \\
\text { time } \\
\text { dummies }\end{array}$ & $\begin{array}{l}\text { Cross-sectional data } \\
\text { of } 6,700 \text { residential } \\
\text { properties located } \\
\text { within Helsinki city for } \\
\text { years } 1980,1985 \\
\text { and } 1989 \text { - The first } \\
\text { year represents pre- } \\
\text { metro rail times, and } \\
\text { the last two years } \\
\text { post-metro rail times. }\end{array}$ & $\begin{array}{l}11 \% \text { property price } \\
\text { increase due to metro rail } \\
\text { on the most desirable } \\
\text { locations, and price } \\
\text { decrease by } 8 \% \text { in the } \\
\text { most remote feeder } \\
\text { transport areas. Positive } \\
\text { impact is highest at the } \\
\text { distance of } 500 \mathrm{~m}-750 \mathrm{~m} \\
\text { from the metro station, } \\
\text { lower at } 250 \mathrm{~m}-500 \mathrm{~m} \text { and } \\
\text { lowest at less than } 250 \mathrm{~m} \text {. }\end{array}$ \\
\hline
\end{tabular}




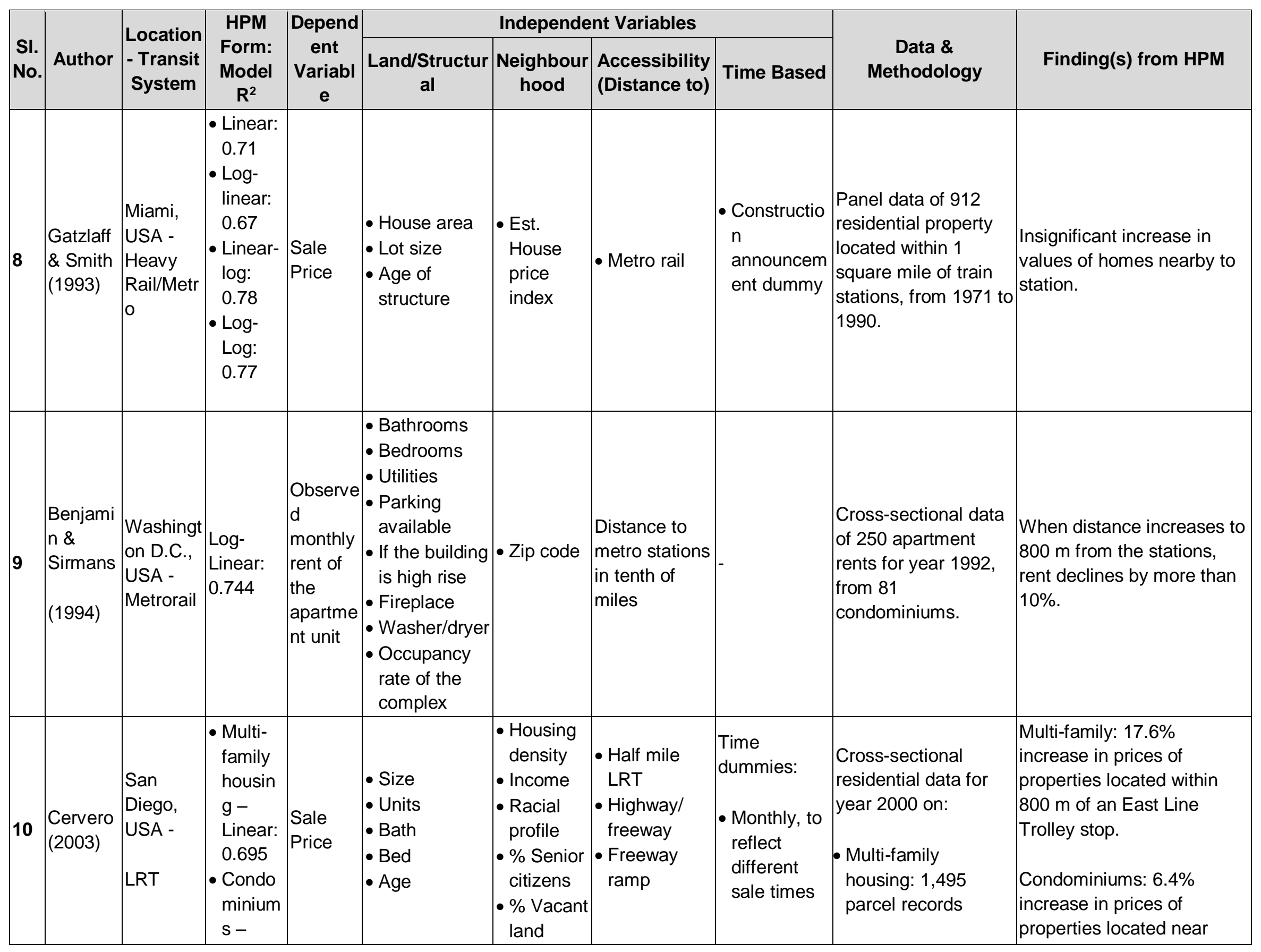




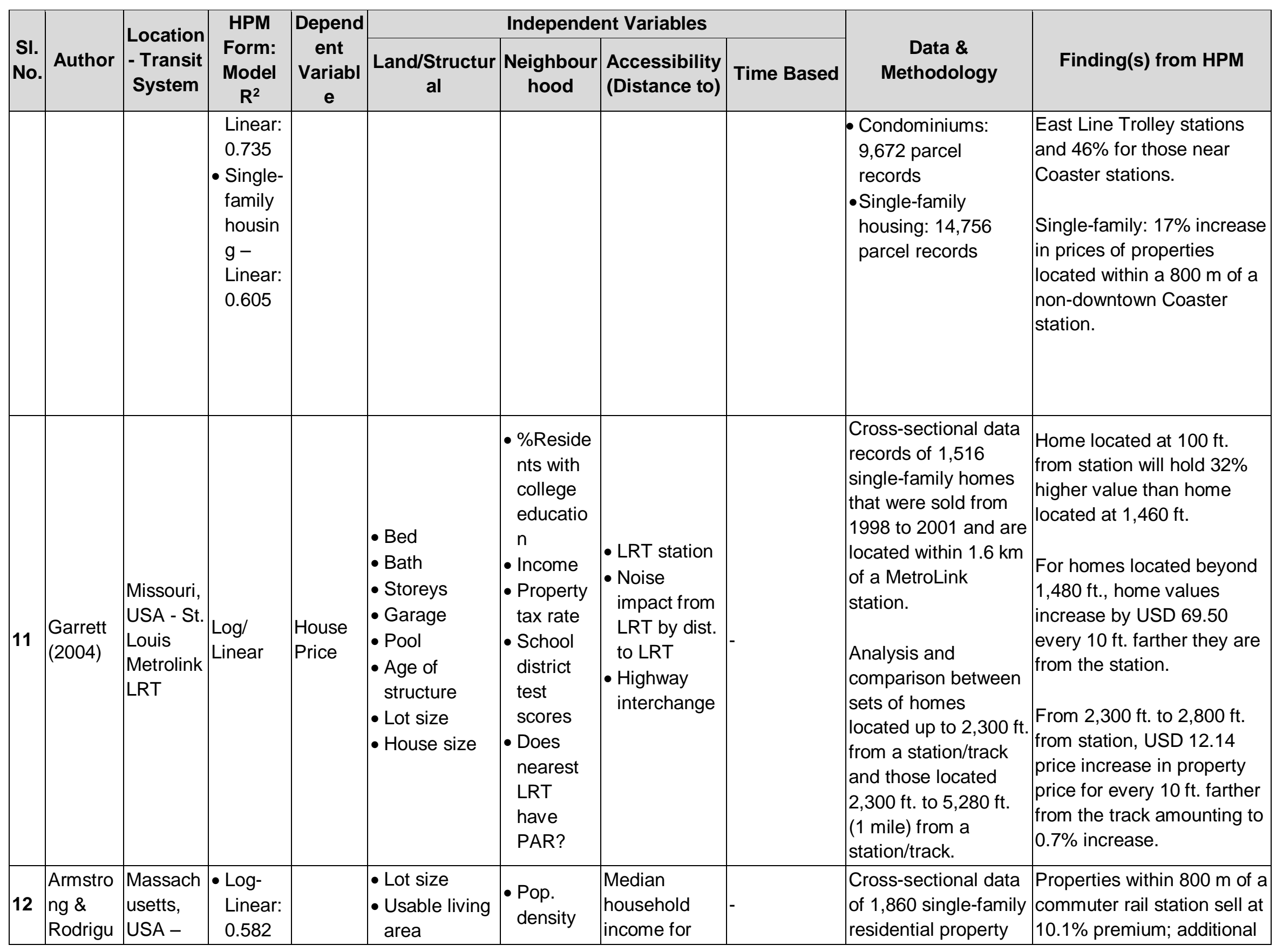




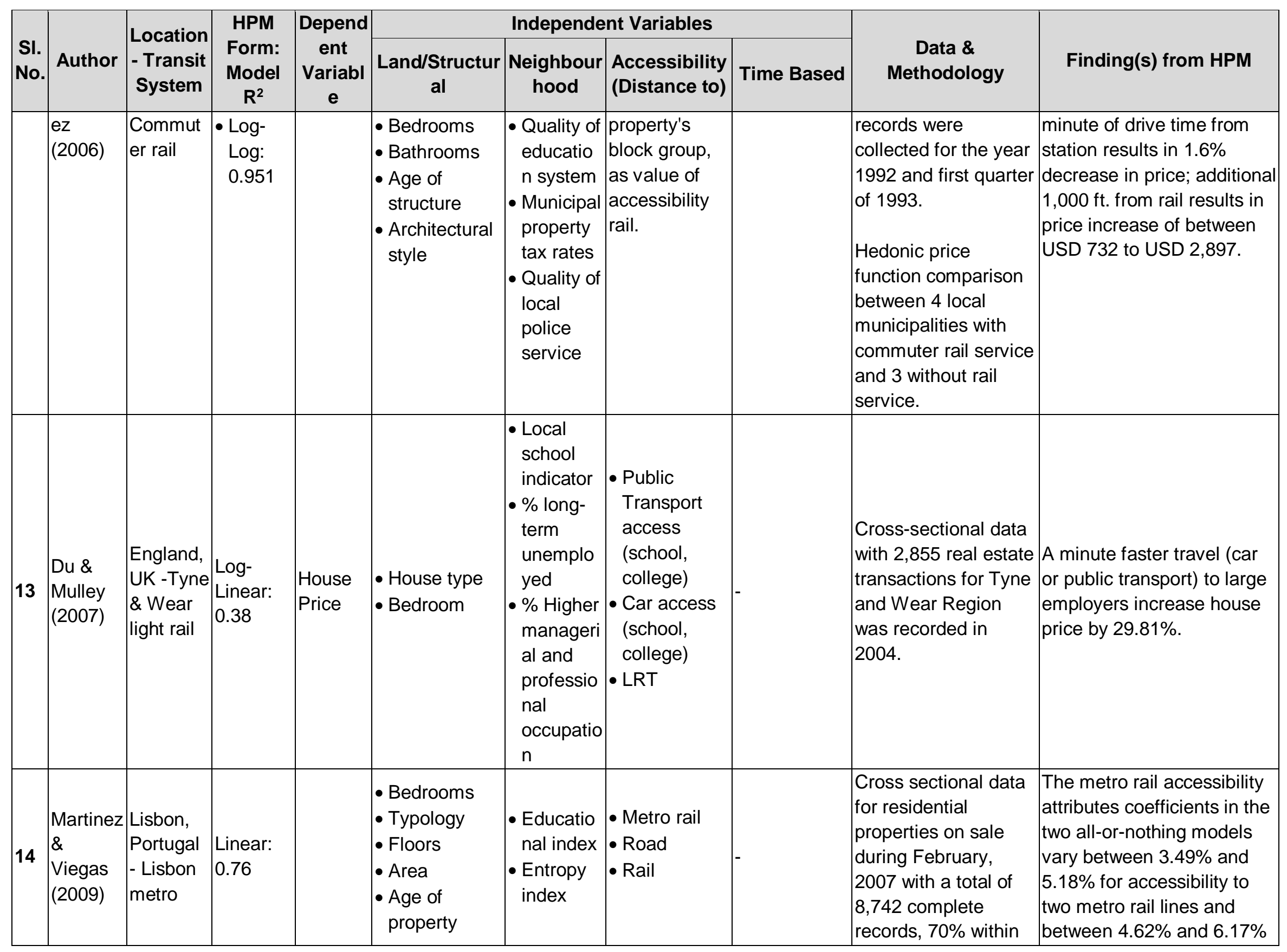




\begin{tabular}{|c|c|c|c|c|c|c|c|c|c|c|}
\hline \multirow[b]{2}{*}{$\begin{array}{l}\text { SI. } \\
\text { No. }\end{array}$} & \multirow{2}{*}{ Author } & \multirow{2}{*}{$\begin{array}{l}\text { Location } \\
\text { - Transit } \\
\text { System }\end{array}$} & \multirow{2}{*}{$\begin{array}{c}\text { HPM } \\
\text { Form: } \\
\text { Model } \\
\mathbf{R}^{2}\end{array}$} & \multirow{2}{*}{\begin{tabular}{|c|} 
Depend \\
ent \\
Variabl \\
e
\end{tabular}} & \multicolumn{4}{|c|}{ Independent Variables } & \multirow[b]{2}{*}{$\begin{array}{c}\text { Data \& } \\
\text { Methodology }\end{array}$} & \multirow[b]{2}{*}{ Finding(s) from HPM } \\
\hline & & & & & $\begin{array}{c}\text { Land/Structur } \\
\text { al }\end{array}$ & $\begin{array}{c}\text { Neighbour } \\
\text { hood }\end{array}$ & $\begin{array}{l}\text { Accessibility } \\
\text { (Distance to) }\end{array}$ & Time Based & & \\
\hline
\end{tabular}




\begin{tabular}{|c|c|c|c|c|c|c|c|c|c|c|}
\hline \multirow[b]{2}{*}{$\begin{array}{l}\text { SI. } \\
\text { No. }\end{array}$} & \multirow[b]{2}{*}{ Author } & \multirow{2}{*}{$\begin{array}{l}\text { Location } \\
\text { - Transit } \\
\text { System }\end{array}$} & \multirow{2}{*}{$\begin{array}{c}\text { HPM } \\
\text { Form: } \\
\text { Model } \\
\mathbf{R}^{2}\end{array}$} & \multirow{2}{*}{\begin{tabular}{|c|} 
Depend \\
ent \\
Variabl \\
e
\end{tabular}} & \multicolumn{4}{|c|}{ Independent Variables } & \multirow[b]{2}{*}{$\begin{array}{c}\text { Data \& } \\
\text { Methodology }\end{array}$} & \multirow[b]{2}{*}{ Finding(s) from HPM } \\
\hline & & & & & $\begin{array}{c}\text { Land/Structur } \\
\text { al }\end{array}$ & $\begin{array}{c}\text { Neighbour } \\
\text { hood }\end{array}$ & $\begin{array}{l}\text { Accessibility } \\
\text { (Distance to) }\end{array}$ & Time Based & & \\
\hline 17 & $\begin{array}{l}\text { Golub, } \\
\text { Guhatha } \\
\text { kurta \& } \\
\text { Sollapur } \\
\text { am } \\
(2012)\end{array}$ & $\begin{array}{l}\text { Phoenix, } \\
\text { USA - } \\
\text { Phoenix } \\
\text { Light Rail } \\
\text { Transit }\end{array}$ & $\begin{array}{l}\text { Log-Log: } \\
0.533\end{array}$ & \begin{tabular}{|l|} 
\\
Adjuste \\
d Sale \\
Price
\end{tabular} & $\begin{array}{l}\text { - Living size } \\
\text { - Lot size } \\
\text { - Age of } \\
\text { structure } \\
\text { - Patios } \\
\text { - Bath } \\
\text { - Floors } \\
\text { - Pool } \\
\text { - TOD zoning }\end{array}$ & - & $\begin{array}{l}\text { - LRT Stn. } \\
\text { - LRT } \\
\text { alignment } \\
\text { - CBD } \\
\text { - Airport }\end{array}$ & $\begin{array}{l}\text { - Time } \\
\text { dummies } \\
\text { - Prior } \\
\text { National } \\
\text { Environmen } \\
\text { t Policy Act } \\
\text { (NEPA) } \\
\text { - During } \\
\text { NEPA } \\
\text { review } \\
\text { - Planning \& } \\
\text { design } \\
\text { - Constructio } \\
\text { n } \\
\text { - Operations }\end{array}$ & $\begin{array}{l}\text { Panel data of } \\
122,222 \text { residential } \\
\text { properties within } 3.2 \\
\text { km from LRT } \\
\text { network, from year } \\
2006-2010 . \\
\text { HPM for was carried } \\
\text { out separately for the } \\
\text { four real estate } \\
\text { markets. }\end{array}$ & $\begin{array}{l}\text { Single-family homes: } \\
\text { Negative impact on prices } \\
\text { of properties located within } \\
200 \mathrm{ft} \text {. of the rail line. } \\
\text { Multi-family homes: } \\
\text { Positive impact on prices } \\
\text { of properties located within } \\
200 \mathrm{ft} \text {. of the rail line. } \\
\text { Vacant properties: } \\
\text { Statistically insignificant. }\end{array}$ \\
\hline
\end{tabular}




\section{Bangalore Metro Context}

The Bangalore Metro project is being executed by the Bangalore Metro Rail Corporation Limited (BMRCL). BMRCL is a special purpose vehicle - a joint venture of the Government of India (Gol) and the Government of Karnataka (state government). Bangalore Metro is being developed in two phases, $42 \mathrm{~km}$ in Phase 1 and $72 \mathrm{~km}$ in Phase 2 (BMRCL, 2016).

Construction of Phase 1 commenced in 2007 and the stations opened in 2011, 2014, 2015 and 2016 (BMRCL, 2016). The last set of stations of Phase 1 are expected to open in April 2017. As of March 2016, Bangalore Metro was operational along $30.28 \mathrm{~km}$ out of the total $42.30 \mathrm{~km}$ of the Phase 1 network (BMRCL, 2016) with average daily ridership of 0.17 million (Indian Express, 2016). Phase 1 has suffered delays throughout its timeline, resulting in over USD 1267 million cost overrun (BMRCL, 2016; Madhavan \& Satyanarayan, 2016). Phase 2 is proposed to start operations by 2020 though construction is yet to commence. Considering the delays in Phase 1, Phase 2 was excluded from this study. Only Phase 1 of Bangalore Metro was considered.

The Gol and the state government together contributed 59\% of Bangalore Metro's project cost while the balance $41 \%$ has been raised as debt from financial institutions including Japan International Corporation Agency, Agence Française Development and Housing and Urban Development Corporation Limited. BMRCL has also raised USD 44 million by issuing bonds (10 year secured), which is significant and representative of the overall financial attractiveness of the project (BMRCL, 2016).

BMRCL incurred a loss of USD 9 million during operations in financial year 2015-16, marginally higher than in 2014-15 (BMRCL, 2016, p. 17). Non-fare box revenue in 2015-16-mainly from property development-amounted to about USD 2.5 million, marginally lower than in 2014-15 (BMRCL, 2016, p. 17). BMRCL argues in the annual report that the financial loss is mainly on account of expansion of the network for commercial operations (BMRCL, 2016, p. 18). They anticipate that revenue will improve substantially as ridership will augment once the entire Phase 1 network is in operation (by April 2017). This approach reflects significant fiscal reliance on fare box revenue.

BMRCL currently owns 35 acres of land and claimed plans to develop it through public private participation and setting up commercial spaces above metro stations. They plan to earn revenue by expanding the norm of 4-FAR (floor area ratio) from $150 \mathrm{~m}$ to $500 \mathrm{~m}$ from operational (not applicable for under-construction or planned) stations (Bangalore Development Authority, 2015). These plans are yet to be executed. BMRCL has missed the opportunity to financially gain from positive impact on real estate value due to metro rail operations till now. On the other hand, private developers are cashing in on this impact of metro rail and planned increase in FAR on land market by buying land parcels for development and redeployment (Satyanarayana, 2016). This signifies that the market is responding to a location-based speculative demand of real estate due by Bangalore Metro project. 
BMRCL could well be in a position to package a rail network with land development to finance the metro rail project. For this, their financial model must include the land value appreciation at different stages of the project. This paper provides the basis for such analysis.

Subsequent sections discuss the methodology and analysis of the impact of Bangalore Metro (Phase 1) on Bangalore real estate.

\section{Bangalore Case Study Methodology}

\subsection{Real Estate Data Collection}

Land/property valuation and registry is essential to efficiently manage this important economic factor of production. India is among the worst ranked countries in land/property registry (The World Bank, 2016). Indian cities lack a comprehensive system to maintain and update urban land records and construction profile (Bheenaveni, 2011). Municipal bodies maintain records of properties for collection of property tax but do not update them annually. If a city like Bangalore is growing rapidly then much of the properties will not be assessed for property tax. Economic Survey of India 2016-17 (Ministry of Finance, 2017) notes that Bangalore has over $80 \%$ of built-up area not assessed.

Government authority real estate prices were not used in this study for the following reasons:

- Government rates are not updated regularly

- No scientific valuation method used for government rates

- Government rates do not incorporate spatial characteristic of property

- Government rates are not based on individual property level valuation

- Government rates are significantly lower than the market rate (Ministry of Finance, 2012)

On the other hand, it is possible to use private real estate data as real estate companies record the sale price of properties and the fluctuation in prices on real time basis. Financial institutions often use real estate company's data for decision making on housing loans which signifies to the authenticity and quality of such data. Therefore, a real estate company (M/s LJ Hookers) data was used in this study which comprised of residential apartment projects (hereafter referred to as property) in Bangalore.

Intrinsic issues related to real estate data availability in India have limited the amount of data used in this study as compared to developed countries cases. For example, McIntosh, Trubka \& Newman (2014) used over 400,000 land value data for a similar study on Perth. Among developing countries' cases, this study employs one of the most comprehensive data comprising of -898 property 
samples $^{5}$ (314,000 apartments) for year 2016; and 458 property samples (160,000 apartments) from 2012 to 2016 on a half yearly basis.

\subsection{Hedonic Price Model's for Bangalore}

This study considered cross sectional data HPM and panel data HPM to evaluate the impact of Bangalore Metro Phase 1. The two different HPM's were included in the study to see if crosssectional data is adequate for achieving LVC results. This is because many emerging cities do not have panel data. Data used for the panel and cross sectional HPM's are at the city-level to estimate the impact of a metro rail project at both city level and the metro rail catchment area. Independent variables and dependent variable used for HPM's are discussed in the next two sections.

\subsubsection{Dependent Variable}

This study uses average sale price of property in Bangalore as a dependent variable for both the cross sectional data HPM and panel data HPM. Cross sectional data comprised of 898 property samples for a single period (June, 2016 in this case). Panel data comprised of 458 property samples for eight time periods between December, 2012 to June, 2016, thus total observations for panel data was 3,664 (458x8) and is important for understanding the impact of metro on property prices over the years.

\subsubsection{Independent Variables}

Independent variables mentioned in the literature review were expanded based on the availability of data and due to the absence of existing empirical studies on factors influencing real estate price in Indian cities to check their impact.

The literature review (Table 1) suggested that independent variables should include city specific, structural, neighborhood and locational variables. Independent variables influencing property price (dependent variable) were considered based on property variables, neighborhood/ socio-economic variables, accessibility variables and metro rail specific variables, as listed in Table 2. City specific independent variables like lake and airport were also included. A total of 22 independent variables were considered in this study but only statistically significant variables were included in both the cross sectional data HPM and panel data HPM.

Additional dummy variables for panel data HPM were included along with the 22 independent variables - eight dummy variable for property prices in December 2012; July 2013; January 2014; July 2014; January 2015; July 2015; January 2016; and July 2016.

\footnotetext{
${ }^{5}$ Each property sample consists of about 350 apartments of varying size and type, which suggests that individual samples hold a substantial quantum for analysis.
} 


\begin{tabular}{|c|c|c|c|}
\hline $\begin{array}{l}\text { Property } \\
\text { variables }\end{array}$ & $\begin{array}{l}\text { Neighborhood/ socio- } \\
\text { economic variables }\end{array}$ & Accessibility variables & Metro rail specific variables \\
\hline $\begin{array}{l}\text { 1. Developer } \\
\text { grade } \\
\text { 2. Project } \\
\text { possession/ } \\
\text { completion } \\
\text { date }\end{array}$ & $\begin{array}{l}\text { 1. Literacy rate } \\
\text { 2. Rented properties } \\
\text { 3. Mix of residential and } \\
\text { commercial } \\
\text { properties (mixed } \\
\text { land use) } \\
\text { 4. Car ownership }\end{array}$ & $\begin{array}{l}\text { Distance from: } \\
\text { 1. Metro station } \\
\text { 2. CBD } \\
\text { 3. Bus stop } \\
\text { 4. Park } \\
\text { 5. Inter-city railway } \\
\text { station } \\
\text { 6. Activity centre } \\
\text { 7. Educational centre } \\
\text { 8. Arterial road } \\
\text { 9. Hospital } \\
\text { 10. Lake } \\
\text { 11. Airport }\end{array}$ & $\begin{array}{l}\text { 1. Nearest metro station } \\
\text { operational year } \\
\text { 2. Nearest metro station } \\
\text { operational status (dummy } \\
\text { variable) } \\
\text { 3. Properties within } 0.5 \mathrm{~km} \\
\text { distance from metro station } \\
\text { (dummy variable) } \\
\text { 4. Properties within } 0.5 \mathrm{~km} \text { to } 1 \\
\text { km distance from metro station } \\
\text { (dummy variable) } \\
\text { 5. Properties within } 1 \mathrm{~km} \text { to } 1.5 \\
\text { km distance from metro station } \\
\text { (dummy variable) }\end{array}$ \\
\hline
\end{tabular}

Independent variables like 'distance from airport' are self-explanatory, however some of them are not and are explained below:

- Neighborhood/ socio-economic variables are at ward level as that is how the data we obtained from Census of India, 2011.

- Developer grade is a qualitative value-related estimate of housing and neighborhood quality. Developer grade data was collected from real estate companies. Grading is performed as good, average and bad, and was based on the following parameters:

- Social and physical infrastructure in the neighbourhood

- Amenities provided by developers within the property

- Income level of neighbourhood

- Construction quality of building

- Absorption rate of the developers' previous projects

- Project completion record history

- Delay/expected delay

- Nearest metro station operational year: This variable was included to estimate the impact of metro rail over the years. Input data for this variable is the 'number of years' from the year the metro rail operations started or are expected to be started at the nearest metro station from the property. The maximum value of this variable is ' 4.7 years' and minimum is ' 4 years'.

- Nearest metro station operational status (operational/ under-construction) (dummy variable): This dummy variable was included to estimate the change in metro rail status from 'under-construction' to 'operational' at the nearest metro station from the property. As the stations of Bangalore Metro were opened in 2011, 2014, 2015 and 2016, this variable captures the impact of metro rail's pivotal stage of becoming operational on land market. 
Four functional forms (linear, log-linear, linear-log and log-log) were tested for both the HPM's. This investigation into the different functional forms of the HPM was necessary as the studies presented in Table 1 used differing functional forms of HPM each and a guidance for best suited form could not be established.

\section{Bangalore Case Study Results}

\subsection{Comparing Panel and Cross Sectional HPM's}

Statistical software (SPSS 22) was used for estimating both HPM's. 'Enter OLS' method was used in SPPS to delineate statistically significant independent variables by multiple iterations and estimate the best fitted model with up to $95 \%$ confidence level. The analysis results in Table $\mathbf{3}$ shows that both cross sectional and panel data are statistically significant. As other emerging cities rarely have property price panel data, Bangalore results suggest that cross sectional data may well be good enough for the city to assess its value capture potential.

Table 3: Model summary and ANOVA ${ }^{6}$ for statistically significant variables

\begin{tabular}{|l|l|r|r|r|r|}
\hline \multirow{4}{*}{ Model } & \multicolumn{3}{|c|}{ Model Summary } & \multicolumn{2}{c|}{ ANOVA } \\
\cline { 2 - 6 } & Function & Adjusted R & $\begin{array}{l}\text { Std. Error of } \\
\text { the Estimate }\end{array}$ & \multicolumn{1}{c|}{ F } & Significance \\
\hline \multirow{2}{*}{\begin{tabular}{l} 
Cross $\begin{array}{l}\text { Sectional } \\
\text { HPM }\end{array}$ \\
\cline { 2 - 6 }
\end{tabular}} & Linear & 0.45 & 2230.77 & 67.19 & 0.000 \\
\cline { 2 - 6 } & Linear-Log & 0.49 & 2147.62 & 86.63 & 0.000 \\
\cline { 2 - 6 } & Log-Linear & 0.5 & 0.28 & 65.83 & 0.000 \\
\hline $\begin{array}{l}\text { Panel Data } \\
\text { HPM }\end{array}$ & Log-Log & $\mathbf{0 . 5 4}$ & $\mathbf{0 . 2 7}$ & $\mathbf{1 0 5 . 1 3}$ & $\mathbf{0 . 0 0 0}$ \\
\hline
\end{tabular}

Table 3 shows that the Ordinary Least Squares (OLS) for cross sectional HPM for the linear, loglinear, linear-log and log-log functional forms displayed varying levels of success in modelling property price and all four functions are not random up to $99.99 \%$. For panel data HPM, only the log-linear functional form was statistically significant for the desired independent variables and not random up to $99.99 \%$.

The log-log functional form of the cross sectional HPM explain the highest variation ${ }^{7}(54 \%)$ in the dependent variable and the log-linear functional form of the panel data HPM explain $64 \%$ of the variation in the dependent variable, thus these were selected for further analysis.

\subsection{Results from Cross Sectional HPM}

\footnotetext{
6 Analysis of variance

${ }^{7}$ An R-square comparison is meaningful as the dependent variable is the same for the models.
} 
Table 4 shows the cross sectional HPM results for the impact of statistically significant independent variables on Bangalore's property price with descriptive statistics. All metro rail related variables were statistically significant in the model and suggest an upward trend of property prices due to metro rail accessibility. It shows $35.8 \%$ value uplift in properties located within $500 \mathrm{~m}$ catchment of a metro station and $19.3 \%$ value uplift in properties located within $500 \mathrm{~m}$ to $1 \mathrm{~km}$ catchment of a metro station. Value uplift in properties located within $1 \mathrm{~km}$ to $2 \mathrm{~km}$ catchment of a metro station is $13.9 \%$. These value uplift trends in properties based on proximity to metro station are similar to that of global cities cases represented in Table 1.

Table 4: OLS Log-Log HPM of Property in Bangalore (2016)

\begin{tabular}{|c|c|c|c|c|c|c|}
\hline $\begin{array}{l}\text { Independent } \\
\text { Variables }\end{array}$ & $\begin{array}{c}\text { Me } \\
\text { an }\end{array}$ & $\begin{array}{c}\text { Std. } \\
\text { Deviation }\end{array}$ & $\begin{array}{l}\% \text { of total } \\
\text { no. of } \\
\text { parcels in } \\
\text { catchment }\end{array}$ & $\begin{array}{l}\text { Coeffici } \\
\text { ents }\end{array}$ & $\begin{array}{l}\text { Signific } \\
\text { ance }\end{array}$ & $\begin{array}{c}\text { \% increase in mean } \\
\text { property price with } \\
\text { a unit in } \\
\text { independent } \\
\text { variables }\end{array}$ \\
\hline (Constant) & & & & 9.91 & 0.000 & \\
\hline $\begin{array}{l}\text { Nearest metro } \\
\text { station } \\
\text { operational year }\end{array}$ & 2.4 & 2.4 & & -0.02 & 0.029 & \\
\hline $\begin{array}{l}\text { Nearest metro } \\
\text { station } \\
\text { operational status } \\
\text { * }\end{array}$ & 0.7 & 0.5 & & 0.11 & 0.008 & $10.90 \%$ \\
\hline $\begin{array}{l}\text { Properties } \\
\text { between } 0.5 \mathrm{~km} \\
\text { to } 1 \mathrm{~km} \text { from } \\
\text { metro station * }\end{array}$ & 0 & 0.1 & $2.10 \%$ & 0.19 & 0.012 & $19.30 \%$ \\
\hline $\begin{array}{l}\text { Properties within } \\
0.5 \mathrm{~km} \text { from } \\
\text { metro station * }\end{array}$ & 0 & 0.2 & $3.30 \%$ & 0.36 & 0.000 & $35.80 \%$ \\
\hline $\begin{array}{l}\text { Properties } \\
\text { between } 1 \mathrm{~km} \text { to } \\
2 \mathrm{~km} \text { from metro } \\
\text { station * }\end{array}$ & 0.1 & 0.2 & $5.50 \%$ & 0.14 & 0.005 & $13.90 \%$ \\
\hline $\begin{array}{l}\text { LN Distance from } \\
\text { metro station }(\mathrm{km})\end{array}$ & 1.8 & 0.9 & & 0.08 & 0.004 & \\
\hline $\begin{array}{l}\text { LN Distance from } \\
\text { CBD }(\mathrm{km})\end{array}$ & 2.4 & 0.5 & & -0.55 & 0.000 & \\
\hline $\begin{array}{l}\text { LN Distance from } \\
\text { bus stop }(\mathrm{km})\end{array}$ & -0.9 & 1 & & -0.03 & 0.006 & \\
\hline $\begin{array}{l}\text { LN Distance from } \\
\text { park }(\mathrm{km})\end{array}$ & -0.3 & 1.3 & & -0.03 & 0.000 & \\
\hline $\begin{array}{l}\text { LN Distance from } \\
\text { airport }(\mathrm{km})\end{array}$ & 3.2 & 0.4 & & -0.12 & 0.000 & \\
\hline
\end{tabular}


Notes:

1. $L N-\log$

2. * - Dummy variable

The results of cross sectional HPM suggests that change in metro rail's operational status from underconstruction to operational raises the property price by $10.9 \%$ across the city. This increase reflects a significant citywide land market response to the availability of new rail transit and the substantial capital investment it brings in the city. Also, the policy to increase FAR along the catchment area after the operation of metro rail could be playing a major role to this increase. This signifies that operation of metro rail is an agglomeration (urban) event that can increase economic productivity of the whole city. Panel data model also shows similar impact at across the city.

Other metro specific variable suggests property values decreases by $1.7 \%$ across the city with each passing year after the commencement metro rail the value uplift due to metro rail in property values. On the contrary this variable has positive impact in the panel data HPM which is a stronger model than the cross sectional one.

\subsection{Results from Panel Data HPM}

Table 5 shows the panel data HPM results for the impact of statistically significant independent variables on Bangalore's property price with descriptive statistics. The statistical significance of property values from 2013 to 2016 shows that the model was strong. Metro rail-related time-variant variables, 'operational year of metro rail' and 'metro rail operational status', were statistically significant and capture the impact of metro rail over the years.

Table 5: OLS Log-Linear HPM of Property Price in Bangalore (2012 to 2016)

\begin{tabular}{|l|r|r|r|r|r|r|}
\hline $\begin{array}{c}\text { Independent } \\
\text { Variables }\end{array}$ & Mean & $\begin{array}{c}\text { Std. } \\
\text { Deviation }\end{array}$ & $\begin{array}{c}\text { of total } \\
\text { no. of } \\
\text { parcels in } \\
\text { catchment }\end{array}$ & Coefficients & Significance & $\begin{array}{c}\% \text { increase } \\
\text { in mean } \\
\text { property } \\
\text { price with a } \\
\text { unit in } \\
\text { independent } \\
\text { variables }\end{array}$ \\
\hline (Constant) & & & & 10.293 & 0.045 & $-53.00 \%$ \\
\hline $\begin{array}{l}\text { Developer's } \\
\text { grade }\end{array}$ & 2.93 & 0.33 & & -0.53 & 0.014 & $-1.60 \%$ \\
\hline $\begin{array}{l}\text { Possession } \\
\text { (in years) }\end{array}$ & 0 & 2.01 & & -0.016 & 0.003 & $1.80 \%$ \\
\hline $\begin{array}{l}\text { Nearest } \\
\text { metro station } \\
\text { operational } \\
\text { year }\end{array}$ & 0.6 & 2.58 & & 0.018 & 0.004 & \\
\hline
\end{tabular}




\begin{tabular}{|c|c|c|c|c|c|c|}
\hline $\begin{array}{l}\text { Independent } \\
\text { Variables }\end{array}$ & Mean & $\begin{array}{c}\text { Std. } \\
\text { Deviation }\end{array}$ & $\begin{array}{l}\% \text { of total } \\
\text { no. of } \\
\text { parcels in } \\
\text { catchment }\end{array}$ & Coefficients & Significance & $\begin{array}{l}\% \text { increase } \\
\text { in mean } \\
\text { property } \\
\text { price with a } \\
\text { unit in } \\
\text { independent } \\
\text { variables }\end{array}$ \\
\hline $\begin{array}{l}\text { Metro rail } \\
\text { operational } \\
\text { status * }\end{array}$ & 0.57 & 0.5 & & 0.045 & 0.019 & $4.50 \%$ \\
\hline $\begin{array}{l}\text { Properties } \\
\text { between } 0.5 \\
\mathrm{~km} \text { to } 1 \mathrm{~km} \\
\text { from metro } \\
\text { station * }\end{array}$ & 0.02 & 0.15 & $2.60 \%$ & 0.253 & 0.027 & $25.30 \%$ \\
\hline $\begin{array}{l}\text { Properties } \\
\text { within } 0.5 \mathrm{~km} \\
\text { from metro } \\
\text { station * }\end{array}$ & 0.03 & 0.16 & $2.40 \%$ & 0.107 & 0.027 & $10.70 \%$ \\
\hline $\begin{array}{l}\text { Properties } \\
\text { between } 1 \\
\mathrm{~km} \text { to } 2 \mathrm{~km} \\
\text { from metro } \\
\text { station * }\end{array}$ & 0.03 & 0.17 & $3.10 \%$ & 0.081 & 0.025 & $8.10 \%$ \\
\hline July 2013 * & 0.13 & 0.33 & & 0.055 & 0.016 & $5.50 \%$ \\
\hline $\begin{array}{l}\text { January } \\
2014 \text { * }\end{array}$ & 0.13 & 0.33 & & 0.134 & 0.017 & $13.40 \%$ \\
\hline July 2014 * & 0.13 & 0.33 & & 0.148 & 0.017 & $14.80 \%$ \\
\hline $\begin{array}{l}\text { January } \\
2015^{*}\end{array}$ & 0.13 & 0.33 & & 0.184 & 0.018 & $18.40 \%$ \\
\hline July $2015^{*}$ & 0.13 & 0.33 & & 0.186 & 0.019 & $18.60 \%$ \\
\hline $\begin{array}{l}\text { January } \\
2016^{*}\end{array}$ & 0.13 & 0.33 & & 0.219 & 0.021 & $21.90 \%$ \\
\hline June 2016 * & 0.13 & 0.33 & & 0.212 & 0.022 & $21.20 \%$ \\
\hline $\begin{array}{l}\text { Distance } \\
\text { from CBD }\end{array}$ & 11.76 & 4.64 & & -0.051 & 0.002 & $-5.10 \%$ \\
\hline $\begin{array}{l}\text { Distance } \\
\text { from bus } \\
\text { stop }\end{array}$ & 0.72 & 0.88 & & -0.048 & 0.006 & $-4.80 \%$ \\
\hline $\begin{array}{l}\text { Distance } \\
\text { from park }\end{array}$ & 1.29 & 1.52 & & -0.024 & 0.004 & $-2.40 \%$ \\
\hline $\begin{array}{l}\text { Distance } \\
\text { from inter- } \\
\text { city railway } \\
\text { station }\end{array}$ & 9.32 & 5.06 & & 0.022 & 0.002 & $2.20 \%$ \\
\hline $\begin{array}{l}\text { Distance } \\
\text { from airport }\end{array}$ & 25.58 & 8.43 & & -0.005 & 0.001 & $-0.50 \%$ \\
\hline $\begin{array}{l}\text { Distance } \\
\text { from } \\
\text { education }\end{array}$ & 1.04 & 1.43 & & 0.051 & 0.005 & $5.10 \%$ \\
\hline
\end{tabular}


Note:

1. *Dummy variable

Model shows an upward trend of property prices due to metro rail related variables. It suggests $10.7 \%$ value uplift in properties located within $500 \mathrm{~m}$ catchment of a metro station and $8.1 \%$ value uplift in properties located within $1 \mathrm{~km}$ to $2 \mathrm{~km}$. The value uplift in properties located within $500 \mathrm{~m}$ to $1 \mathrm{~km}$ catchment of a metro station is $25.3 \%$ value uplift in properties - higher than the properties with greater accessibility to metro stations. The difference is attributable to noise levels, vibrations due to high speed rail and prolonged construction related inconvenience due to delay in construction and other reasons discussed in the next section.

At city level, change in metro rail's operational status from under-construction to operational raises the property price by $4.5 \%$. This increase reflects a significant citywide land market response to the availability of new rail transit and the substantial capital investment it brings in the city. Also, the policy to increase FAR along the catchment area after the operation of metro rail could be playing a major role to this increase. This signifies that operation of metro rail is an agglomeration (urban) event that can increase economic productivity of the whole city. Other metro specific variable suggests $1.8 \%$ value uplift in properties with each passing year after the metro rail became operational.

The analysis shows that developer grade is a significant variable as it yields $53 \%$ appreciation in property prices with improvement in grade. This underscores the importance of quality of development, facilities in the property, neighbourhood and other property specific parameters. Whilst a year's delay in possession of a property reduces its price by $1.6 \%$-- in practical terms, the property owner loses rental value with delay in possession.

\section{Discussion}

Although the cross sectional data and the panel data HPM's cannot be directly compared due to different independent variables used in the models, both models displayed metro rail specific variables as statistically significant and generally reflected similar trends. As the panel data HPM is a stronger model and shows the impact of metro on property prices over the years, it has been used to assess the significance of WTP and draw conclusions in the study. In the next two sub-sections, we attempt to explain the panel data HPM results that are summarized in Figure 2 for the rail catchment area and across the whole city. 


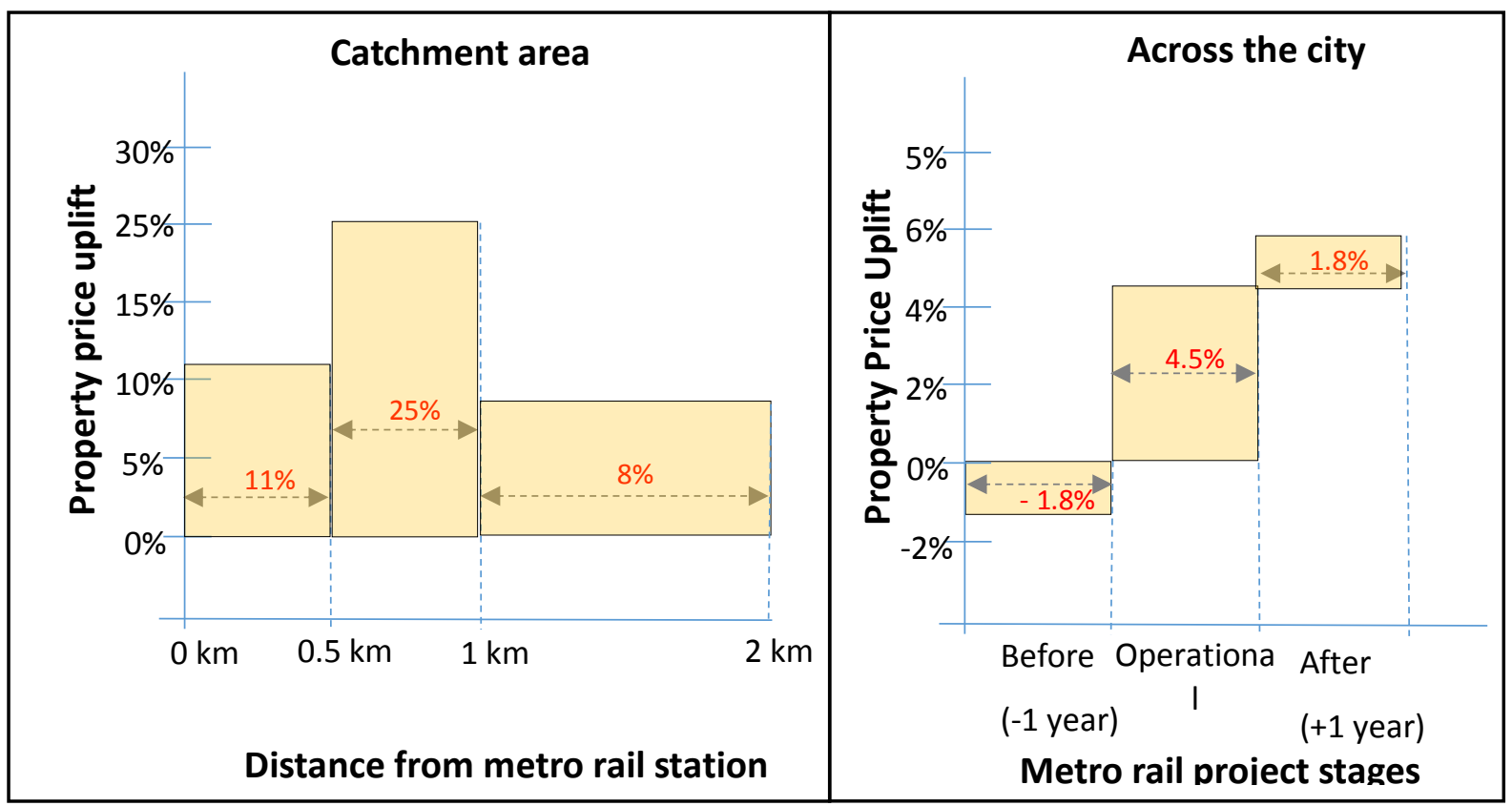

Figure 2: Impact of metro rail on property price

\subsection{Property Price Impact - Metro Rail Catchment Area}

Bangalore's panel data HPM shows that the impact of metro rail in the catchment areas goes beyond the traditional influence zone of $500 \mathrm{~m}$. The property value increase $(25 \%)$ in properties located within the $500 \mathrm{~m}$ to $1 \mathrm{~km}$ catchment is higher than the value (11\%) in properties located within $500 \mathrm{~m}$ from a metro station. This redefines the generally acceptable theory of increasing of land value with the proximity to urban rail which was also shown in the studies on Perth, Australia (Mclntosh, Trubka \& Newman, 2014) and Helsinki, Finland (Laakso, 1992).

The generic reasons of the decreasing land value in the catchment area can be due to the negative externalities for residential land market adjacent to the high intensity stations - higher noise levels, vibrations due to high-speed rail, prolonged construction and intense traffic flow as most of the rail stations are located on the arterial roads. These negative externalities can be applicable to most of the cities. Specific reasons for the case of Bangalore seems to be - the construction prolonged for over 2 years than planned; due to absence of policies to guide any land use change before or during implementation of metro rail, the metro rail triggers gradual commercialization prior to its operation commencement (Singh \& Sharma, 2012). The land use change is mostly unplanned and piecemeal, while it further attracts informal and hawking activity in the vicinity of metro stations. The phenomenon is peculiar to emerging cities. Also, the $500 \mathrm{~m}$ to $1,000 \mathrm{~m}$ station catchment is well served by paratransit modes like auto rickshaw/ taxi/ cycle rickshaw which enables easy access beyond walking and cycling, though these modes creates highly crowded conditions in the immediate surrounding of the stations. Thus the land value increases in the immediate surroundings of the metro rail but the higher values are found just beyond these very crowded areas. These reasons may impact the 
residential property buyer willingness to reside in $500 \mathrm{~m}$ to $1,000 \mathrm{~m}$ catchment area over residing within $500 \mathrm{~m}$ catchment. This also help explain the $8 \%$ increase out to the $1-2 \mathrm{~km}$ catchment.

This decreasing land value in the catchment area of Bangalore Metro also extend Luca Bertolini model on 'node' and 'place' by finding a decreasing land valuation without proper planning within the urban rail catchment (Bertolini \& Spit, 2005). He suggested that real estate value is likely to be generated more from the place than the node, although both are important but people choose to live in places, not nodes.

\subsection{Property Price Impact - City Level}

The metro rail specific variables 'operational year of metro rail' and 'metro rail operational status' in the city level HPM have revealed substantial agglomeration benefits of the metro rail even out to 29 $\mathrm{km}$ radius from metro stations ${ }^{8}$. The $4.5 \%$ increase in property price across the whole city ${ }^{9}$ due to the opening of the metro is a very strong economic impact for an infrastructure - this city level increase was suggested in the urban rent and demand theories discussed in this paper. This is rarely measured in any HPM study on urban rail impacts and has significant policy implications.

The extent of the impact, across the whole city, is not generally understood by some economists and agencies who do not see property uplift from rail as a general economic benefit but only as a local catchment area benefit shifting economic value from one area to another. This research shows that urban rail value uplift covers the whole city. It may suggest that other value uplift studies could examine the extent to which the whole city benefits however it may be that it is too small to measure in a developed city.

It is perhaps easy to understand why there would be such an economic impact in an emerging city, such as Bangalore for the following reasons:

a) Investment: The substantial capital investment metro rail projects bring in the city helps to accelerate economic activity of a city and such investment is highly significant in Bangalore.

The cost of Phase 1 of Bangalore Metro is USD 2,068 million (BMRCL, 2016), about two times (USD 1,005 million) the size of the municipal budget of Bangalore (Nag, 2015). Such investment can be hypothesized to have a larger economic impact than has been seen in developed cities due to its proportional investment impact. Transportation being the engine of the urban economy tends to have much more accumulated impact as a sector since it has relevance to all the existing

\footnotetext{
${ }^{8}$ The mean distance from metro to properties was $7.8 \mathrm{~km}$ and $75 \%$ were located within $10 \mathrm{~km}$ 9 Uplift in the capital value of Bangalore's property market is 2.5\% (Compounded Annual Growth Rate) from 2012 to 2016 (LJ Hookers, 2017).
} 
industries and inhabitants of the city. Recalling the location theories, metro rail projects (transportation) can be seen to be playing an elemental role in shaping a city's demand.

b) Travel Time: Significant economic growth potential is being blocked by large scale traffic congestion in most dense, emerging cities like Bangalore; hence a metro rail can unlock significantly greater economic opportunity through this improvement in accessibility. The difference in accessibility between emerging cities and developed cities means that far greater agglomeration benefits can be obtained due to the proportionally bigger accessibility gains. Newman \& Kenworthy (2015) show that the ratio of transit speeds to traffic speeds of global cities are highest in Asian cities (0.86) as compared to developed cities (0.69) due to very low traffic speeds. The developed cities still have higher traffic speed and lower infrastructure deficits as compared to emerging cities so as new urban rail projects are built in emerging cities there are dramatic accessibility benefits.

In Bangalore the dramatic population growth in recent times (42\% over the last decade of 20012011) resulting in 9 million trips every day (2015) has reduced travel speeds from $18 \mathrm{kph}$ in 2008 to $11 \mathrm{kph}$ in 2015 (survey of $375 \mathrm{~km}$ of major road network by the Bangalore Development Authority, 2017). In the city center it was lower than $10 \mathrm{kph}$ in 2011 (Karnataka Urban Infrastructure Development \& Finance Corporation, 2011). The Bangalore Metro's average speed is $34 \mathrm{kph}$ (BMRCL, 2017) and its existing network is connecting the CBD (with south-north and north-south rail corridor) and its planned extension will connect all major economic centers of Bangalore. The travel speed is important for a growing city like Bangalore which has an average trip length of about $10 \mathrm{~km}$ (in 2015) that has increased from $9 \mathrm{~km}$ (in 2011) (Bangalore Development Authority, 2017; Karnataka Urban Infrastructure Development \& Finance Corporation, 2011).

The combined effect of low traffic speed and increasing trip length affects travel time reliability (Taylor, 2013). A significant factor metro rail adds over other modes is the reliability to reach destination on time - a major factor in workforce travel behaviour (Carrion \& Levinson, 2012) and hence in generating accessibility benefits.

A study done by a cab aggregator, OLA (2015, as cited in Rao, 2015), showed that average traffic speed in all major Indian cities is about $19 \mathrm{kph}$ and the average travel time is 34.8 minutes to reach workplace. This would explain why Indian cities are demanding and implementing metro rail projects that have a reliable average speed of $35 \mathrm{kph}$. Delhi, where transport has the largest share of road land use among all major Indian cities, witnessed traffic speeds of $20 \mathrm{kph}$ in 2013 and is constructing the biggest metro rail system in India (MoUD, 2013). A study on mode choice modelling of private and public modes in Delhi showed that travel time is more significant than travel cost and other factors according to both modes users (Sharma, 2011).

\subsection{Willingness to Pay (WTP)}


WTP for metro rail transit is calculated by multiplying the catchment hedonic price and the average property value. WTP with respect to proximity to metro stations in Bangalore is shown in Table 6.

Table 6: Willingness to Pay for Bangalore Metro

\begin{tabular}{|l|l|l|}
\hline \multicolumn{1}{|c|}{ Proximity to Metro Station } & \multicolumn{1}{c|}{$\begin{array}{c}\text { Property Value Uplift (Panel } \\
\text { Data HPM) }\end{array}$} & \multicolumn{1}{|c|}{ WTP per sq. $\mathbf{m}$. } \\
\hline At $0-0.5 \mathrm{~km}$ & $11 \%$ & INR 5,016 (USD 75) \\
\hline At $0.5-1 \mathrm{~km}$ & $25 \%$ & INR 11,862 (USD 172) \\
\hline At $1-2 \mathrm{~km}$ & $8 \%$ & INR 3,800 (USD 54) \\
\hline At whole city & $4.5 \%$ & INR 1,033 (USD 32) \\
\hline
\end{tabular}

The WTP for change in metro rail's operational status across the whole city in the panel data HPM sample of 458 property results in an aggregate WTP of USD 360 million $^{10}$, whilst the total cost of Phase 1 of the Bangalore Metro is about USD 2,068 million (BMRCL, 2016). This is substantial value creation.

\subsection{Policy Implications}

Based on this study the following policy implications are suggested:

1. Bangalore shows that metro rail can not only uplift value around stations but across the whole city. This would suggest metro rail has a major strategic role in any emerging city's economy.

2. In order to fund metro rail systems, cities like Bangalore can venture into alternative financing via value capture mechanisms. There is clearly value uplift happening. The extent of value uplift can be used to determine value capture mechanisms:

a. The $11 \%, 25 \%$ and $8 \%$ value capture in the catchment areas ( 0 to $2 \mathrm{~km}$ ) could have a Beneficiary Zoning Levy, and

b. The $4.5 \%$ value uplift across the whole city could be a Public Transport Levy on all new developments.

3. The reduced uplift values next to stations suggests more attention should be given to a Local Area Station Management Plan and Walkable Urban Design Plan to create more walkable spaces (Matan \& Newman, 2016).

4. This study has shown that Bangalore's existing policy to sell density zoning after the metro rail is operational proves to be financially correct as the uplift peaks $(4.5 \%)$ during the opening of metro rail. Nevertheless, the policy to allow density zoning to properties within only $150 \mathrm{~m}$ (and proposed $500 \mathrm{~m}$ ) from operational metro station needs to be amended as the impact of metro rail is citywide.

${ }^{10}$ Each apartment was about 70 sq.m. and each apartment project has about 350 apartments. 


\section{Conclusion}

This study shows that urban rail has substantially increased property value in Bangalore. The impact of metro rail is beyond the traditional $500 \mathrm{~m}$ and it to have reached right across the city. The increase in the whole city indicates a major agglomeration economic event resulting in substantial willingness to pay of USD 306 million. This increased willingness to pay in Bangalore now will demand changes in the policy and density zoning that will benefit land markets by pushing them to their highest value and best use. These benefits qualify to be recognized by the policy makers and be used to build urban rail as a maximizer for economic development. Although it is too late for this phase of the Bangalore Metro, other phases could plan to tap such an increase for funding. Other emerging cities can be given some confidence about using the value capture mechanisms as well to build or expand urban rail.

The findings of this study disrupts the traditional theory of increasing of land value with the proximity to urban rail. We have explained these findings based on theories and peculiar factors in Bangalore, and implications of these findings on urban policy have been discussed. The analysis of this study can help other emerging cities to quantify the impact of urban rail and help explain its findings as there are limited academic studies on emerging cities. Thus the analyses and the detailed literature review of this paper can benefit policymakers to make informed decisions on urban rail projects.

\section{Disclosure:}

1. The authors of this paper would like to thank:

a. Dr. Giovanni Perucca for his important comments on methodology of HPM's.

b. M/s LJ Hookers for providing the real estate data.

2. Funding for research was provided by Curtin University Sustainability Policy Institute, Curtin University, through the provision of a PhD scholarship to Rohit Sharma.

3. This paper is one of a series of papers, as part of the PhD on Financing Urban Rail Projects through Land Value Capture - The Indian Case. 


\section{Bibliography}

1. Achen, C. H. (1982). Interpreting and using regression. Newbury Park, CA: Sage Publications.

2. Alonso, W. (1964). Location and land use. Cambridge, MA: Harvard University Press.

3. Armstrong, R. J., \& Rodriguez, D. A. (2006). An evaluation of the accessibility benefits of commuter rail in eastern Massachusetts using spatial hedonic price functions. Transportation, 33(1), 21-43. DOI:10.1007/s11116-005-0949-x

4. Anantsuksomsri, S., \&Tontisirin, N. (2015). The impacts of mass transit improvements on residential land development values: Evidence from the Bangkok Metropolitan Region. Urban Policy and Research, 33(2), 195-216. http://dx.doi.org/10.1080/08111146.2014.982791

5. Atkinson-Palombo, C. (2010). Comparing the capitalisation benefits of light-rail transit and overlay zoning for single-family houses and condos by neighbourhood type in metropolitan Phoenix, Arizona. Urban Studies, 47(11), 2409-2426. DOI: 10.1177/0042098009357963.

6. Bae, C. H. C., Jun, M. J., \& Park, H. (2003). The impact of Seoul's subway Line 5 on residential property values. Transport policy, 10(2), 85-94. http://dx.doi.org/10.1016/S0967-070X(02)00048-3

7. Bangalore Development Authority. (2015). Revised Master Plan 2015 - Bangalore. Retrieved from www.bdabangalore.org/Zoning_Regulations_RMP2015f.pdf

8. Bangalore Metro Rail Corporation Limited (BMRCL). (2017). Project Highlights. Retrieved from www.bmrc.co.in/English/ProjectHighlights.htm

9. Bangalore Metro Rail Corporation Limited (BMRCL). (2016). 10th Annual Report 2015-16.

Retrieved from www.bmrc.co.in/pdf/finance/10thannualreport-English.pdf

10. Benjamin, J. D., \&Sirmans, G. S. (1994). Mass transportation, apartment rent and property values. The Journal of Real Estate Research, 12(1), 1-8. Retrieved from http://pages.jh.edu/jrer/papers/pdf/past/vol12n01/v12p001.pdf

11. Bertolini, L., \& Spit, T. (2005). Cities on rails: The redevelopment of railway stations and their surroundings. Oxford: Routledge.

12. Bheenaveni, R. (2011). Urban management in India. Raleigh, NC: Lulu Publications

13. Black, E. (2007). Internal Combustion: How Corporations and Governments Addicted the World to Oil and Derailed the Alternatives. London: Macmillan.

14. Camagni, R. (2016). Afterthoughts on urban economic theory and its focus. Journal of Regional Research, 36, 87-105. Retrieved from http://www.aecr.org/images/ImatgesArticles/2016/12/04_Camagni.pdf.

15. Capello, R. (2011). Location, regional growth and local development theories. AESTIMUM, 58, 125. Retrieved from www.fupress.net/index.php/ceset/article/download/9559/8912.

16. Carrion, C., \& Levinson, D. (2012). Value of travel time reliability: A review of current evidence. Transportation research part A: policy and practice, 46(4), 720-741. http://dx.doi.org/10.1016/j.tra.2012.01.003

17. Cervero, R. (2003). Effects of light and commuter rail transit on land prices: Experiences in San Diego County. Retrieved from http://fltod.com/research/general_tod/effects_of_light_and_commuter_rail_transit_on_land_prices. pdf.

18. Chen, C. L. (2012). Reshaping Chinese space-economy through high-speed trains: opportunities and challenges. Journal of Transport Geography, 22, 312-316.

doi:10.1016/j.jtrangeo.2012.01.028

19. Debrezion, G., Pels, E., \& Rietveld, P. (2007). The impact of railway stations on residential and commercial property value: a meta-analysis. The Journal of Real Estate Finance and Economics, 35(2), 161-180. DOI:10.1007/s11146-007-9032-z

20. Du, H., \& Mulley, C. (2007). Transport accessibility and land value: a case study of Tyne and Wear. Retrieved from http://citeseerx.ist.psu.edu/viewdoc/download?doi=10.1.1.111.4163\&rep=rep1\&type=pdf.

21. Fischer, M. M., \& Nijkamp, P. (2014). Handbook of regional science. Berlin: Springer. 
22. Garrett, T. A., (2004). Light-Rail Transit in America: Policy issues and prospects for economic development. Retrieved from

https://www.stlouisfed.org/ /media/Files/PDFs/Community\%20Development/Research\%20Report s/light_rail.pdf.

23. Gatzlaff, D. H., \& Smith, M. T. (1993). The impact of the Miami Metrorail on the value of residences near station locations. Land Economics, 69(1), 54-66. DOI: 10.2307/3146278.

24. Glaeser, E. (2011). Triumph of the city: How our greatest invention makes us richer, smarter, greener, healthier, and happier. London: Penguin.

25. Golub, A., Guhathakurta, S., Sollapuram, B. (2012). Spatial and temporal capitalization effects of light rail in Phoenix from conception, planning, construction to operation. Journal of Planning Education and Research, 32(4), 415-429. DOI: 10.1177/0739456X12455523.

26. Granger, C. W., \& Newbold, P. (1976). The use of R2 to determine the appropriate transformation of regression variables. Journal of Econometrics, 4(3), 205-210. http://dx.doi.org/10.1016/03044076(76)90032-4

27. Green, O. (2016). Rails in the Road: A History of Tramways in Britain and Ireland. Barnsley, SY: Pen and Sword.

28. Gu, Y. (2006). The impacts of rail transit on property values: Empirical study in Beijing. Retrieved from http://www.asres2007.umac.mo/papers/044\%20-\%20PAPER.pdf.

29. Gujarati, D., \& Porter, D. C. (2004). Basic econometrics. London: McGraw-Hill.

30. Haig, R. M. (1926). Toward an understanding of the metropolis: II. The assignment of activities to areas in urban regions. The Quarterly Journal of Economics, 40(3), 402-434. DOI: https://doi.org/10.2307/1885172

31. Hurd, R. M. (1903). Principles of city land values. New York, NY: Record and Guide.

32. Iacono, M., Levinson, D., Zhao, J., \&Lari, A. (2009). Value capture for transportation finance: Report to the Minnesota Legislature (Value Capture for Transportation Finance Series, Report No. CTS 09-18S). Minneapolis: University of Minnesota Center for Transportation Studies. www.cts.umn.edu/research/featured/value-capture

33. Indian Express (2016) Metro posts Rs 60 crore loss, hopes to break even in 2016-17. www.newindianexpress.com/states/karnataka/2016/oct/16/metro-posts-rs-60-cr-loss-hopes-tobreak-even-in-2016-17-1528343.html

34. Isard, W. (1956). Location and space-economy: A general theory relating to industrial location, market areas, land use, trade, and urban structure. Cambridge, MA: MIT Press.

35. Jillella, S. S. K., \& Newman, P. (2016). Innovative value capture based rail transit financing: an opportunity for emerging transit cities of India. Journal of Sustainable Urbanization, Planning and Progress. http://ojs.whioce.com/index.php/jsupp/article/view/70.

36. Karnataka Urban Infrastructure Development \& Finance Corporation. (2011). Comprehensive Traffic \& Transportation Plan for Bengaluru. Retrieved from wricitieshub.org/sites/default/files/Comprehensive\%20Traffic\%20and\%20Transportation\%20Plan \%20for\%20Bangalore.pdf

37. Kirwan, R. (1966). Book Review: Location and land use: Toward a general theory of land rent. Urban Studies, 3(2), 171-173. DOI: 10.1080/00420986620080371

38. Kivell, P.T. \& Shaw, G. (1988). The study of retail location. In J. Dawson (Ed.), Retail Geography (RLE Retailing and Distribution) pp. 95-156. New York, NY: Routledge.

39. Laakso, S. (1992). Public transport investment and residential property values in Helsinki. Scandinavian Housing and Planning Research, 9(4), 217-229. DOI: http://dx.doi.org/10.1080/02815739208730308

40. Lin, J., Hwang, C. (2003). Analysis of property prices before and after the opening of the Taipei subway system. Annals of Regional Science, 38, 687-704. DOI: 10.1007/s00168-003-0185-2

41. LJ Hooker (2017) Bangalore Residential Research Report Jan - 2017. Bangalore: LJ Hooker.

42. Madhavan, R. \&Satyanarayan, S. (2016). Bengaluru: Rocked by the rocks, Metro 1 not so fast!.Retrieved from www.deccanchronicle.com/nation/current-affairs/160916/bengaluru-rockedby-the-rocks-metro-1-not-so-fast.html 
43. Martínez, L., \&Viegas, J. (2009). Effects of transportation accessibility on residential property values: Hedonic Price Model in the Lisbon, Portugal, metropolitan area. Transportation Research Record: Journal of the Transportation Research Board, (2115), 127-137.

DOI: http://dx.doi.org/10.3141/2115-16

44. Matan, A., \& Newman, P. (2016). People Cities: The Life and Legacy of Jan Gehl. Washington D.C.: Island Press.

45. McIntosh, J., Trubka, R., \& Newman, P. (2014). Can value capture work in a car dependent city? Willingness to pay for transit access in Perth, Western Australia. Transportation Research Part A: Policy and Practice, 67, 320-339. Retrieved from http://dx.doi.org/10.1016/j.tra.2014.07.008

46. Medda, F., \&Modelewska, M. (2009). Land value capture as a funding source for urban investment: The Warsaw Metro system. London: UCL QASER Lab

47. Ministry of Finance. (2012). Black money. Retrieved from www.thehindubusinessline.com/multimedia/archive/01091/WhitePaper_BackMon_1091518a.pdf

48. Ministry of Finance. (2017). Economic Survey 2016-17. Retrieved from indiabudget.nic.in/es2016-17/echapter.pdf

49. Ministry of Urban Development (MoUD). (2012). Innovative financing metro rail projects. Retrieved from http://moud.gov.in/upload/uploadfiles/files/Innovative\%20financing\%20on\%20Metro\%20rails.pdf

50. Ministry of Urban Development (MoUD). (2013). Urban transport service level benchmarking for Indian cities. New Delhi: Ministry of Urban Development, Government of India.

51. Muth, R. M. (1969). Cities and housing: The spatial pattern of urban residential land use. Chicago, IL: University of Chicago Press.

52. Nag, A. (2015). BBMP's 6728 crore budget: Yet another unrealistic financial plan for the city? Retrieved from http://bangalore.citizenmatters.in/articles/bbmp-budget-2015-analysis-bangalore.

53. Nagelkerke, N. J. (1991). A note on a general definition of the coefficient of determination. Biometrika, 78(3), 691-692. Retrieved from http://www.cesarzamudio.com/uploads/1/7/9/1/17916581/nagelkerke_n.j.d._1991_a_note_on_a_general_definition_of_the_coefficient_of_determination.pdf.

54. Newman, P., \&Kenworthy, J. (2015). The end of automobile dependence: How cities are moving beyond car-based planning. Washington D.C.: Island Press.

55. Newman, P., Kenworthy, J., Glazebrook, G. (2013). Peak car use and the rise of global rail: Why this is happening and what it means for large and small cities. Journal of Transportation Technologies, 3, 272-287. http://dx.doi.org/10.4236/jtts.2013.34029.

56. Park, R. E. (1929). Urbanization as measured by newspaper circulation. American Journal of Sociology, 35(1), 60-79. DOI: 10.1086/214918

57. Park, R. E. (1952). Human communities. New York, NY: The Free Press. http://lawschool.unm.edu/nrj/volumes/06/1/16_coblentz_location.pdf

58. Ratcliff, R. U. (1949). Urban land economics. London: McGraw-Hill

59. Rao, S. (2015). Bengaluru, Kolkata slowest moving metros. Retrieved from timesofindia.indiatimes.com/city/bengaluru/Bengaluru-Kolkata-slowest-movingmetros/articleshow/50390186.cms

60. Rosen, S. (1974). Hedonic prices and implicit markets: product differentiation in pure competition. Journal of Political Economy, 82(1), 34-55. http://dx.doi.org/10.1086/260169

61. Satyanarayana, K. (2016). Builders seized by FAR factor as metro grows. bangaloremirror.indiatimes.com/bangalore/cover-story/Builders-seized-by-F-A-R-factor-as-Metrogrows/articleshow/54009654.cms.

62. Scott, J. C. (1976). The moral economy of the peasant. New Haven, CT: Yale University Press.

63. Shankar, A. (2015). Railways-Metro Rails in India offer an unmatched realty catalyst. Retrieved from http://articles.economictimes.indiatimes.com/2015-07-27/news/64919146_1_metro-railmetro-corridor-land-values

64. Sharma, R. (2011). Mode Choice Modelling for MRTS Corridor - Delhi. (Unpublished Bachelor's thesis.) Maulana Azad National Institute of Technology, Bhopal, India. 
65. Sharma, R. (2018). Financing Indian Urban Rail through Land Development: Case Studies and Implications for the Accelerated Reduction in Oil Associated with $1.5^{\circ} \mathrm{C}$. Urban Planning, 3(2), 21-34. DOI: 10.17645/up.v3i2.1158

66. Sharma, R., \& Newman, P. (2017). Urban Rail and Sustainable Development Key Lessons from Hong Kong, New York, London and India for Emerging Cities. Transportation Research Procedia, 26, 92-105. DOI: 10.1016/j.trpro.2017.07.011.

67. Sharma, R., \& Newman, P. (2018). Can land value capture make PPP's competitive in fares? A Mumbai case study. Transport Policy, 64, 123-131. DOI: 10.1016/j.tranpol.2018.02.002

68. Singh, M., \& Sharma, R. (2012). Financing options for transit system through real estate - Case of Rohinisubcity, Delhi. Paper prepared for European Transport Conference, Glasgow. Retrieved from http://abstracts. aetransport.org/paper/index/id/4005/confid/18.

69. Sraffa, P. (1960). Production of commodities by means of commodities: Prelude to a critique of economic theory. Cambridge, MA: Cambridge University Press.

70. Sopranzetti, B. J. (2015). Hedonic regression models. In C. Lee \& J. Lee (Eds.), Handbook of financial econometrics and statistics (pp. 2119-2134). New York, NY: Springer.

71. Taylor, M. A. (2013). Travel through time: the story of research on travel time reliability. Transportmetrica B: transport dynamics, 1(3), 174-194. http://dx.doi.org/10.1080/21680566.2013.859107

72. The World Bank. (2016). Economy ranking. Retrieved from www.doingbusiness.org/rankings.

73. Von Thunen, J. H. (1966). Von Thunen's isolated state: An English edition of Der IsolierteStaat (C. M. Wartenberg, Trans.). Oxford: Pergamon Press. (Original work published 1826)

74. Wingo, L. (1961). Transportation and urban land. Baltimore, MD: John Hopkins University Press.

75. Yankaya, U. (2004). Modeling the impacts of Izmir subway on the values of residential property using hedonic price model. (Master's thesis) Retrieved from http://citeseerx.ist.psu.edu/viewdoc/download?doi=10.1.1.427.4661\&rep=rep1\&type=pdf

76. Zhang, M., \& Wang, L. (2013). The impacts of mass transit on land development in China: The case of Beijing. Research in Transportation Economics, 40, 124-133.

http://dx.doi.org/10.1016/j.retrec.2012.06.039. 